\title{
Effect of nitrogen fertiliser on the rate of lipid peroxidation of different maize hybrids
} in a long-term multifactorial experiment

\author{
Á. Illés ${ }^{1 *}\left(\mathbb{0}\right.$, Cs. Bojtor $^{1}$, A. Széles ${ }^{1}$, S.M.N. Mousavi ${ }^{1}$, \\ B. Tóth ${ }^{2}$ and J. Nagy ${ }^{1}$
}

\footnotetext{
${ }^{1}$ Institute of Land Utilisation, Technology and Regional Development, Faculty of Agricultural and Food Sciences and Environmental Management, University of Debrecen, Debrecen, Hungary

${ }^{2}$ Institute of Nutrition, Faculty of Agricultural and Food Sciences and Environmental Management, University of Debrecen, Böszörményi út 138, H-4032 Debrecen, Hungary
}

\section{ORIGINAL RESEARCH PAPER}

Received: June 29, 2020 • Accepted: November 10, 2020

Published online: February 6, 2021

(C) 2020 The Author(s)

\section{ABSTRACT}

The presented research aimed to confirm that the differences in the lipid peroxidation of three maize (Zea mays L.) hybrids with different genotypes and maturity are due to different nitrogen levels, which was observed based on the amount of malondialdehyde (MDA) measured in the leaves at the main phenological stages of plants. The experiments were performed in a multi-factorial long term fertilisation field trial. In the study, phosphorus and potassium were constantly provided at the optimal level for the plants. The phosphorus and potassium fertilisation were applied in autumn. However, $\mathrm{N}$ levels varied from 0 to $300 \mathrm{~kg}$ $\mathrm{ha}^{-1}$. Sampling was done at different growth stages 5 times during the growing season (4 leaves, 6 leaves, 8 leaves, 14 leaves, silking). The $300 \mathrm{~kg} \mathrm{ha}^{-1} \mathrm{~N}$ (dose 3) resulted in a significant increase in lipid peroxidation (MDA level), but not a statistically significant difference between the control (dose 1) and the $120 \mathrm{~kg} \mathrm{ha}^{-1}$ (dose 2) $\mathrm{N}$ doses. The H1 hybrid had the lowest level of lipid peroxidation at the first sampling date. High volume nitrogen fertilisation (dose 3: $300 \mathrm{~kg} \mathrm{ha}^{-1}$ ) increased lipid peroxidation in the hybrids. Averaging the values obtained for the same hybrid at the different sampling times, the medium (dose 2) $120 \mathrm{~kg} \mathrm{ha}^{-1} \mathrm{~N}$ treatment had no significant effect on the lipid peroxidation of the hybrids compared to the values of the control plants. Based on the lipid peroxidation response of the hybrids to $\mathrm{N}$ treatment, the exact $\mathrm{N}$ dose

\footnotetext{
*Corresponding author. E-mail: illes.arpad@agr.unideb.hu
} 
inflection point can be determined to make the fertiliser utilisation of plants more efficient. Based on our results, we found that inadequate, low $\left(120 \mathrm{~kg} \mathrm{ha}^{-1}\right)$ or high $\left(300 \mathrm{~kg} \mathrm{ha}^{-1}\right)$ nitrogen fertilisation could affect the MDA levels of plants, thereby affecting the functioning of the lipid peroxidation mechanism.

\section{KEYWORDS}

macronutrients, MDA, monoculture, phenological stages, stress

\section{INTRODUCTION}

Precision crop production and precision nutrient replenishment are essential factors in modern agricultural practice. New maize hybrids can be classified with the help of accurate knowledge of plant nutrient requirements and responses. As our climate becomes extreme, the weather exposure to crop production will increase further, which will require the production of hybrid lines that successfully adapt to the environment. Different hybrids are bred to meet different environmental and cultivation technology needs, one of the most important demands being abiotic and biotic stress tolerance. Depending on the type, cultivar, age, and soil conditions, nitrogen is absorbed by plants in the form of ammonium $\left(\mathrm{NH}^{4+}\right)$ or nitrate $\left(\mathrm{NO}^{3-}\right)$ (Tömösközi-Farkas et al., 2014).

Lipids and oils may be damaged during food storage. It can be caused by enzyme actions but also by temperature changes. Peroxide formation is the most significant out of the oxidative changes. Peroxidation of lipids takes place in a system with active oxygen that is associated with a high degree of instability of unsaturated fatty acids. Peroxidation of fatty acids in foods leads to undesirable changes in taste and odour, a decrease in enjoyment value (St Angelo et al., 2009). Studying lipid peroxidation that causes flavour degradation in raw materials and foods plays an important role in controlling quality in the food industry requires and plays an important role in flavour degradation in raw materials and foods (Kosáry et al., 2002). Oxidation products, when reacting with other food components, may cause several adverse changes (discolouration, digestibility of proteins, and loss of biological value). Odour and taste changes during the storage of cereals are due to lipid oxidation, during which volatile and non-volatile substances are formed (Doblado-Maldonado et al., 2012) Due to lipid peroxidation, volatile compounds with intense odour can be detected in foods. These include unsaturated acyl lipids, aldehydes, ketones, and carboxylic acids. The reduction or prevention of the oxidation of lipids increases the enjoyment value of stored crops significantly (Heiniö et al., 2003). Trans fatty acids in foods can pose a serious health risk, cardiovascular diseases may develop due to excessive consumption, and their legislation is of outmost importance inside and outside of the EU as well (Zuchowska-Grzywacz and Kowalska, 2019). Sargis and Subbaiah (2003) found that trans unsaturated fatty acids are less oxidisable than cis forms and protect endogenous lipids from oxidation in lipoproteins.

Plant stress means any change of the optimal growth and development factors, which may alter or damage the metabolic homeostasis of the plants. As a result of the changes induced by the stress factors, new metabolic and physiological pathways must be created to restore the metabolic balance of the plants. This process is called acclimatisation (Shulaev et al., 2008).

According to the findings of Larcher (1987), plant stress contains both constructive and destructive elements that act as selection factors and allow for better resistance, and together 
constitute the driving force for adaptive evolution. Under stress, plants produce signalling molecules that trigger a process that affects the ability of plants to acclimatise, but can also lead to programmed cell death (Nabi et al., 2019).

The correlation between the functioning of the antioxidant defence system of plants and the degree of lipid peroxidation has been the subject of several studies (Gossett et al., 1994; Hernández and Almansa, 2002). Lipid peroxidation is a marker process that can be used to monitor the stress status of plants. In the scope of the research of Bojtor and co-workers (2019) performed with edible beans (Phaseolus vulgaris L.), artificial biotic stress increased the amount of malondialdehyde (MDA) in plants with an average of $14.03 \mathrm{nmol} \mathrm{MDA} / \mathrm{g}$ FW to $76.78 \pm 9.18$, i.e., increased lipid peroxidation was observed. In the scope of the examination of lipid peroxidation, the degree of generated MDA indicates the degree of activity of the process (Heath and Packer, 1968). Research findings support the view that signalling mediated by reactive lipid forms is involved in some physiological processes, including, but not limited to, apoptosis and induction of antioxidant defence (Bhattacharjee, 2014). The present research aimed to evaluate the differences in lipid peroxidation of three maize hybrids (Zea mays L.) with different genotypes and maturity in the main phenological stages of plants based on the level of MDA measured in the leaves.

\section{MATERIALS AND METHODS}

The experiment was performed at the Látókép Crop Production Experimental Plant of the University of Debrecen with three maize (Zea mays L.) hybrids of different genotypes (Hybrid 1: FAO 400, Hybrid 2: FAO 490, Hybrid 3: FAO 380). The long-term experiment started 1986 and has been running with unchanged nutrient supplementation since then. We measured the MDA levels of hybrids in 2019 growing season. In the studied experimental area, there was a positive temperature difference between April and September in the average of the summer periods of the last 5 years compared to the 30-year average (Gombos and Nagy, 2019).

The trial of multiple decades provides the possibility for the long-term study of the effects of nutrient supply, eliminating the discrepancy due to environmental and agro-technical variables. In the scope of base cultivation, autumn deep ploughing and autumn base fertiliser were applied. In the examined plots, phosphorus and potassium were constantly provided at the optimal level for the plant by autumn application, but the nitrogen supplementation varied between 0 and 300 $\mathrm{kg} \mathrm{ha}^{-1}$ (Dose 1: $0 \mathrm{~kg} \mathrm{ha}^{-1} \mathrm{~N}$, Dose 2: $120 \mathrm{~kg} \mathrm{ha}^{-1} \mathrm{~N}$, Dose 3: $300 \mathrm{~kg} \mathrm{ha}^{-1} \mathrm{~N}$ ). There was no additional nutrient supplementation in the control plots either organic or inorganic for the last 30 years. From a pedological point of view, the area is calcareous chernozem soil formed on loess, Arany's plasticity index is $\mathrm{K}_{\mathrm{A}}=43-45$, level of humus content is average $(\mathrm{Hu} \%=2.7-$ 2.8), the thickness of the humus layer is around $80 \mathrm{~cm}$ (Nagy, 2019).

Sampling was performed 5 times during the growing season. Sampling times were based on heat sums and phenological phases: 1st sampling 4 leaves - 153 heat sum, 2nd sampling 6 leaves - 221 heat sum, 3rd sampling 8 leaves - 341 heat sum, 4th sampling 14 leaves -630 heat sum, and 5th sampling silking - 779 heat sum. One gram of green plant leaf sample was collected without the leaf vein at the same time of day at 9 am after dew drying.

Samples were taken from the 4 th adult leaf during the first three samplings, from the 10th adult leaf at the 4 th samplings, and the leaf opposite the ear at the last sampling. After sampling, samples were transported in liquid nitrogen and stored in $\mathrm{a}-80^{\circ} \mathrm{C}$ deep freezer until processing. 
Concentrations of lipid peroxides were calculated from the MDA content. MDA was determined based on the description of Thomas et al. (2004), with an extinction coefficient of $155 \mathrm{mM}^{-1} \mathrm{~cm}^{-1}$ given for $1 \mathrm{~g}$ fresh weight.

$$
\text { Concentration of } \operatorname{MDA}(\mathrm{mM})=\left(\mathrm{A}_{532}-\mathrm{A}_{600}\right) / 155
$$

As for its design, the experiment is a two-factor, striped, four-replicate, small-plot, long-term field experiment that allows for appropriate statistical evaluation. Sampling was conducted in 5 replications. The statistical analysis was performed in $\mathrm{R}$ studio 3.2.4. The graphs were created with MS Excel 2019.

\section{RESULTS AND DISCUSSION}

The physiological responses of maize grown with the application of a large amount of fertiliser (300 $\mathrm{kg} \mathrm{ha}^{-1} \mathrm{~N}$ (dose 3)) have long raised the question of how the antioxidant defence system responds and what effect it has on lipid peroxidation.

As a result of nitrogen fertilisation, the amount of MDA measured in maize leaves changed significantly during the growing season. Dose $300 \mathrm{~kg} \mathrm{ha}^{-1} \mathrm{~N}$ (dose 3) resulted in a significant increase in MDA content, but there was no statistical difference between $0 \mathrm{~kg} \mathrm{ha}^{-1}$ (dose 1) and $120 \mathrm{~kg} \mathrm{ha}^{-1}$ (dose 2) $\mathrm{N}$ treatments. Between sampling times, MDA levels changed significantly at all three nutrient levels (Fig. 1).

The amounts of MDA measured in the examined hybrids differed during the vegetation period. The H1 hybrid had the lowest level of lipid peroxidation at the first sampling time (Fig. 2). For $\mathrm{H} 1$ and $\mathrm{H} 3$ hybrids, the MDA content showed an increasing trend during the early

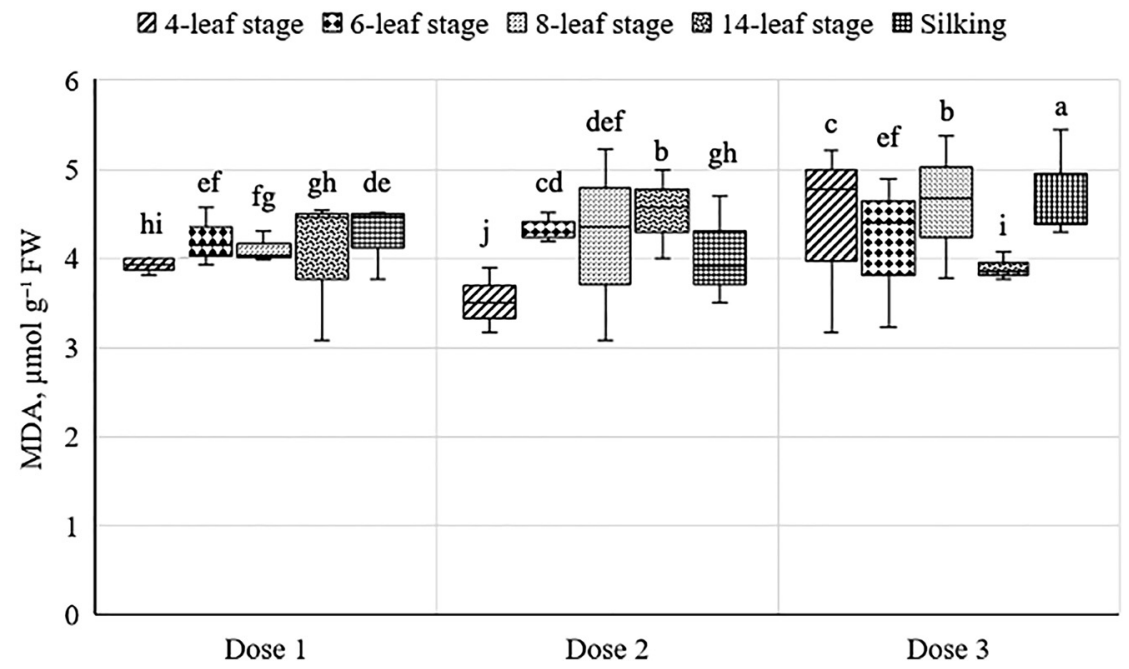

Fig. 1. Effect of different nitrogen fertilisation levels on the amount of malondialdehyde (MDA) of maize at different sampling dates $\left(\mathrm{LSD}_{5}=0.207, n=15\right)\left(\right.$ Dose $1=0 \mathrm{~kg} \mathrm{ha}^{-1} \mathrm{~N}$, Dose $2=120 \mathrm{~kg} \mathrm{ha}{ }^{-1} \mathrm{~N}$, Dose $3=300 \mathrm{~kg} \mathrm{ha}^{-1} \mathrm{~N}$ ) 


\section{4-leaf stage 6-leaf stage 1 8-leaf stage 14 -leaf stage 田 Silking}

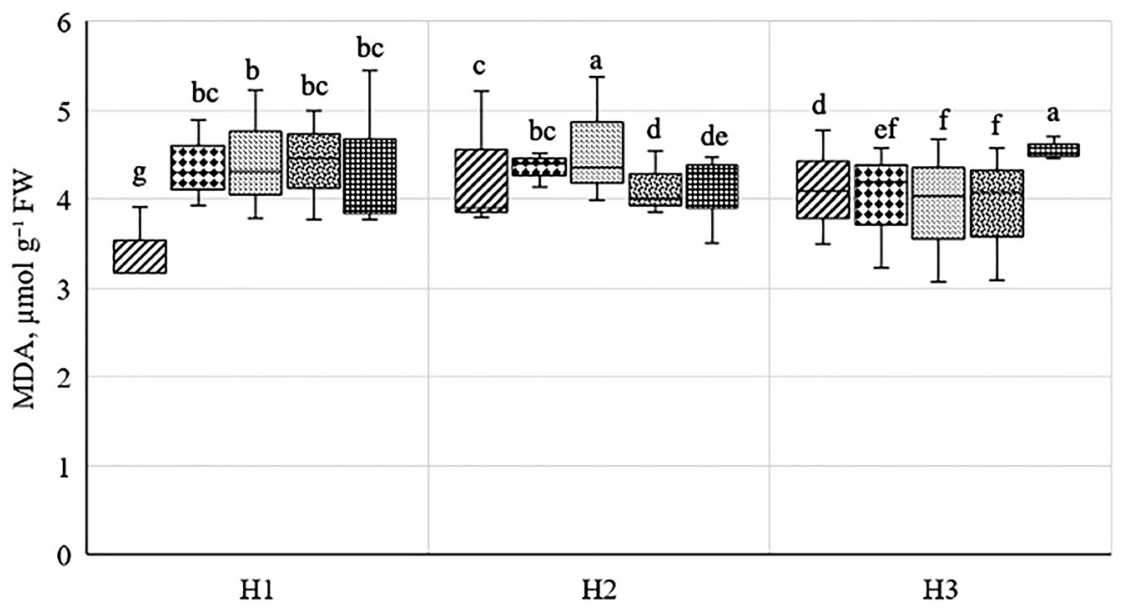

Fig. 2. Amount of malondialdehyde (MDA) of maize hybrids at different sampling dates $\left(\mathrm{LSD}_{5}=0.020\right.$, $n=15)$ Hybrid 1: FAO 400, Hybrid 2: FAO 490, Hybrid 3: FAO 380)

stage of growing season and then for $\mathrm{H} 1$ it decreased from the 14-leaf stage, whereas for $\mathrm{H} 3$ hybrid it increased at the end of the growing season.

There was a statistically significant difference in lipid peroxidation between 4 leaf, 8 leaf, 14 leaf and silking in each hybrids. There was no difference between $0 \mathrm{~kg} \mathrm{ha}^{-1}$ and $120 \mathrm{~kg} \mathrm{ha}^{-1}$ in the lipid peroxidation of the $\mathrm{H} 1$ and $\mathrm{H} 2$ hybrids during the 6-leaf stage sampling.

In the early developmental phase, the $\mathrm{H} 2$ hybrid had higher MDA values than the $\mathrm{H} 1$ hybrid, but between the 8-leaf and 14-leaf stages, i.e. in the phenological phases, the stage of the ear formation (8 leaf - 14 leaf) was lower important on differentiation the level of MDA, as was lipid peroxidation. The MDA levels of $\mathrm{H} 1$ and $\mathrm{H} 2$ increased during the growing season until 8-leaf stage and then decreased as the growing season progressed (Fig. 3.)

On the average of nitrogen doses and sampling dates, the lowest MDA level was measured for the $\mathrm{H} 3$ hybrid, therefore this hybrid had the highest capacity for toleration of biotic or abiotic stresses (Fig. 4A).

High level nitrogen fertilisation (dose 3) of $300 \mathrm{~kg} \mathrm{ha}^{-1}$ increased the lipid peroxidation of the hybrids. In the average MDA values of the sampling times, the control (dose 1) and medium (dose 2, $120 \mathrm{~kg} \mathrm{ha}^{-1} \mathrm{~N}$ ) nitrogen fertilisation had no significant effect on the lipid peroxidation of the hybrids (Fig. 4A). For each examined hybrid, $300 \mathrm{~kg} \mathrm{ha}^{-1} \mathrm{~N}$ (dose 3) fertiliser supplementation significantly increased the MDA content (Fig. 4B).

Nitrogen plays an important role in antioxidant defence enzymes of maize and lipid peroxidation metabolism of stress products (Zhang and Liu, 2001). Zhan and co-workers (2007) showed that high-dose macronutrient fertilisation, especially nitrogen, could influence the antioxidant enzyme system and the degree of lipid peroxidation. Depending on the amount of nitrogen fertilisation the extent of lipid peroxidation varies, thereby sharpening the effect of transition at the end of the growing season and having an effect on senescence. Similar results 


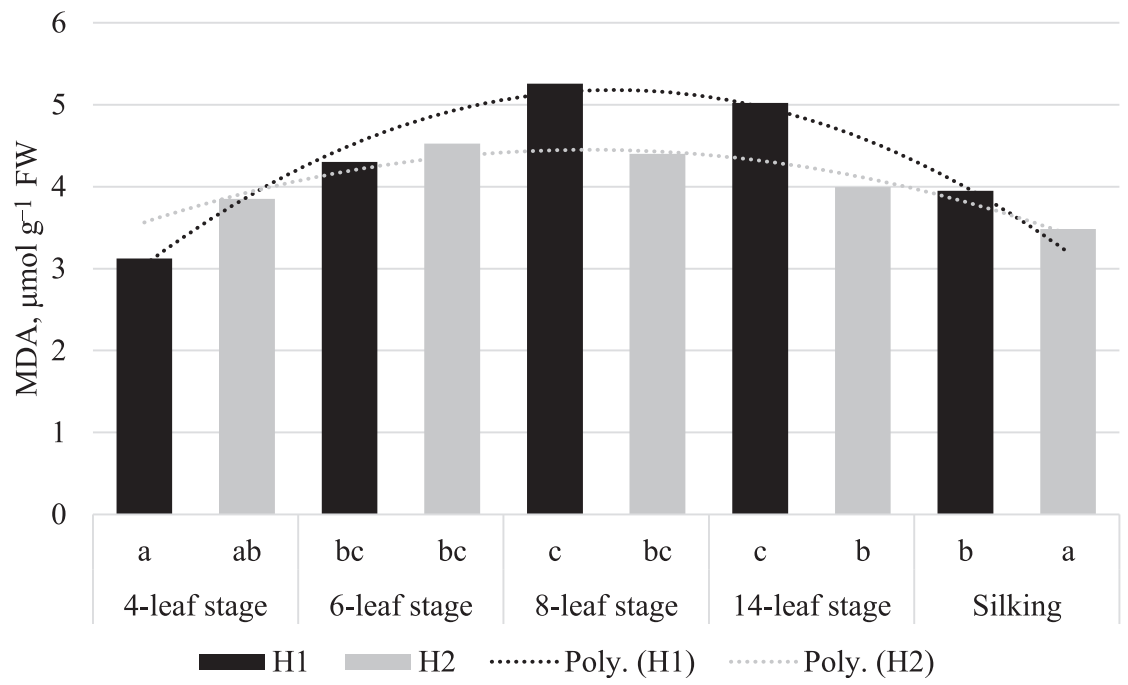

Fig. 3. Effect of $120 \mathrm{~kg} \mathrm{ha}^{-1} \mathrm{~N}$ on the amount of malondialdehyde (MDA) of maize hybrids at 5 development stages $\left(\mathrm{LSD}_{5}=0.049, n=15\right)$
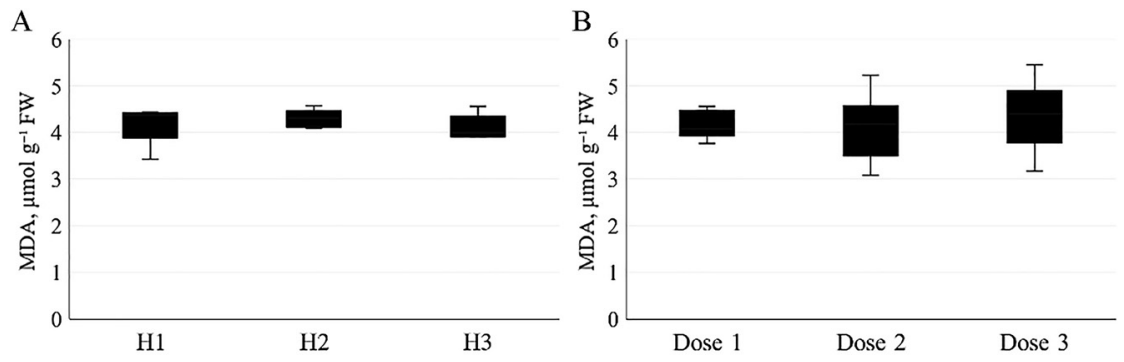

Fig. 4A. Average lipid peroxidation of maize hybrids during the growing season $\left(\mathrm{LSD}_{5}=0.053, n=75\right)$ (Hybrid 1: FAO 400, Hybrid 2: FAO 490, Hybrid 3: FAO 380). 4B. Average effect of different nitrogen fertilisation levels on the lipid peroxidation of maize $\left(\mathrm{LSD}_{5}=0.053, n=75\right)$ (Dose $1=0 \mathrm{~kg} \mathrm{ha}^{-1} \mathrm{~N}$, Dose $2=120 \mathrm{~kg} \mathrm{ha}^{-1} \mathrm{~N}$, Dose $3=300 \mathrm{~kg} \mathrm{ha}^{-1} \mathrm{~N}$ )

were obtained in the studies of Liu and co-workers (2012), where excessive nitrogen fertilisation increased the rate of lipid peroxidation. Therefore, moderate $\mathrm{N}$ application is an effective method to prevent the early senescence of leaves. Improper, low or high, levels of nitrogen fertilisation might interfere with the functioning of the antioxidant enzyme system and thereby increasing the amount of MDA. Excessive nitrogen addition can increase lipid peroxidation increasing the MDA content reducing leaf photosynthesis under water stress according to Kong and co-workers (2017). The results show that the addition of nitrogen increases the production and drought tolerance of products by increasing the activities of antioxidant enzymes and reducing lipid peroxidation as stated by Zhan and co-workers (2007). 


\section{CONCLUSIONS}

The degree of nitrogen fertilisation had a significant effect on the measurable MDA content in the leaves at every sampling time. There was no statistical difference in the MDA levels between the control (dose 1) and the $120 \mathrm{~kg} \mathrm{~N} \mathrm{ha}^{-1}$ (dose 2) nutrient level, but the high nutrient level of $300 \mathrm{~kg} \mathrm{~N} \mathrm{ha}^{-1}$ (dose 3) significantly increased lipid peroxidation at every sampling time from the 4-leaf stage until silking. There was a difference in the degree of lipid peroxidation between the three examined hybrids. Averaging all obtained values from every sampling time and $\mathrm{N}$ supplementation levels, the lowest MDA level was obtained for the $\mathrm{H} 3$ hybrid. Overall, the examination of lipid peroxidation in the critical phenological phases of cultivation may provide information on the response of hybrids to stress conditions and may be suitable for indirect studies of the precise, in-depth physiological effects of fertilisation.

\section{ACKNOWLEDGEMENT}

The research was financed by the Higher Education Institutional Excellence Programme (NKFIH-1150-6/2019) of the Ministry of Innovation and Technology in Hungary, within the framework of the 4th thematic programme of the University of Debrecen, and supported by the ÚNKP-19-3 New National Excellence Program of the Ministry for Innovation and Technology.

\section{REFERENCES}

Bhattacharjee, S. (2014). Membrane lipid peroxidation and its conflict of interest: the two faces of oxidative stress. Current Science India, 107(11): 1811-1823.

Bojtor, C., Győri, Z., Sipos, P., Radócz, L., and Tóth, B. (2019). Effect of bean rust [Uromyces appendiculatus (Pers.) Strauss] on photosynthetic characteristics, superoxide-dismutase activity, and lipid peroxidation of common bean (Phaseolus vulgaris L.). Acta Alimentaria, 48: 253-259.

Doblado-Maldonado, A.F., Pike, O.A., Sweley, J.C., and Rose, D.J. (2012). Key issues and challenges in whole wheat flour milling and storage. Journal of Cereal Science, 56(2): 119-126.

Gombos, B. and Nagy, J. (2019). Weather evaluation based on long-term maize (Zea mays L.) experiment data. Növénytermelés, 68(2): 5-24.

Gossett, D.R., Millhollon, E.P., and Lucas, M.C. (1994). Antioxidant response to $\mathrm{NaCl}$ stress in salt-tolerant and salt-sensitive cultivars of cotton. Crop Science, 34(3): 706-714.

Heath, R.L. and Packer, L. (1968). Photoperoxidation in isolated chloroplasts: I. Kinetics and stoichiometry of fatty acid peroxidation. Archives of Biochemistry and Biophysics, 125(1): 189-198.

Heiniö, R.-L., Liukkonen, K.-H., Katina, K., Myllymäki, O., and Poutanen, K. (2003). Milling fractionation of rye produces different sensory profiles of both flour and bread. LWT - Food Science and Technology, 36(6): 577-583.

Hernández, J.A. and Almansa, M.S. (2002). Short-term effects of salt stress on antioxidant systems and leaf water relations of pea leaves. Physiology Plantarum, 115(2): 251-257. 
Kong, L., Xie, Y., Hu, L., Si, J., and Wang, Z. (2017). Excessive nitrogen application dampens antioxidant capacity and grain filling in wheat as revealed by metabolic and physiological analyses. Science Report, 7(1): 43363.

Kosáry, J., Takács, M., and Siró, I. (2002). Intensive test for studying lipid peroxidation. Acta Alimentaria, 31: $57-62$.

Larcher, W. (1987). Streß bei Pflanzen. Naturwissenschaften, 74: 158-167.

Liu, Y., Wang, R., Hua, L., and Xie, Z. (2012). Effects of N applied rate on leaf senescence and protective enzyme system at later growth stage of maize. (In Chinese with English abstract). Journal of Maize Sciences, 20(2): 124-127.

Nabi, R.B.S., Tayade, T., Hussain, A., Kulkarni, K.P., Imran, Q.M., Mun, B.G., and Yun, B.W. (2019). Nitric oxide regulates plant responses to drought, salinity, and heavy metal stress. Environmental and Experimental Botany, 161: 120-133.

Nagy, J. (2019). Complex long-term experiments on soil use, water and nutrient management at the University of Debrecen since 1983. Növénytermelés, 68(3): 5-28.

Sargis, R.M. and Subbaiah, P.V. (2003). Trans unsaturated fatty acids are less oxidizable than cis unsaturated fatty acids and protect endogenous lipids from oxidation in lipoproteins and lipid bilayers. Biochemistry, 42(39): 11533-11543.

Shulaev, V., Cortes, D., Miller, G., and Mittler, R. (2008). Metabolomics for plant stress response. Physiology Plantarum, 132(2): 199-208.

St Angelo, A.S., Vercellotti, J., Jacks, T., and Legendre, M. (2009). Lipid oxidation in foods. Critical Reviews in Food Science and Nutrition, 36(3): 175-224.

Thomas, J.C., Perron, M., and Davies, E.C. (2004). Genetic responsiveness to copper in the ice plant, Mesembryanthemum crystallinum. Plant Science, 167(2): 259-266.

Tömösközi-Farkas, R., Berki, M., Nagy-Gasztonyi, M., Wolf, I., and Polgár, Z. (2014). Investigation of antinutritive components in Hungarian potato cultivars depending on production technology. Acta Alimentaria, 43: 188-196.

Zhan, X.M., Han, X.R., Yang, J.F., Wang, S., Gao, M., and Zhao, L.Y. (2007). Effect of different fertilizer supply of maize on protective enzyme activities and lipid peroxidation of leaves in latter stage. (In Chinese with English abstract). Journal of Maize Sciences, 1.

Zhang, L.X., Li, S.X., Zhang, H., and Liang, Z.S. (2007). Nitrogen rates and water stress effects on production, lipid peroxidation and antioxidative enzyme activities in two maize (Zea mays L.) genotypes. Journal of Agronomy and Crop Science, 193(6): 387-397.

Zhang, S.G. and Liu, G.L. (2001). Plant nutrition and drought resistance of crops. (In Chinese with English abstract). Chinese Bulletin of Botany, 18(1): 64-69.

Zuchowska-Grzywacz, M. and Kowalska, M. (2019). Trans fatty acids in food - current legal regulations as protections for consumers and food manufactures. Acta Alimentaria, 48: 105-114.

Open Access. This is an open-access article distributed under the terms of the Creative Commons Attribution 4.0 International License (https://creativecommons.org/licenses/by/4.0/), which permits unrestricted use, distribution, and reproduction in any medium, provided the original author and source are credited, a link to the CC License is provided, and changes - if any - are indicated. (SID_1) 